Comentários críticos 


\section{Comentários sobre o FLORAM}

\section{OSWALDO SEVA*}

1. Presenciei três reuniōes do grupo que está elaborando o programa (em 18 jul., 20 set. e 11 out.) como observador e como professor-visitante do Instituto de Estudos Avançados no campo das Ciências Ambientais.

Informo que o projeto de pesquisa que aqui desenvolvo está centrado nos temas do Risco Tecnológico e das Alteraçōes da Dinâmica Natural decorrentes de alguns dos principais processos produtivos industriais e energéticos; e que, deste ponto de vista, uma das alteraçóes principais é o aumento da concentração de $\mathrm{CO}_{2}$, resultante da queima de combustíveis fósseis, da queima de lenha e carvão vegetal, e do corte da cobertura vegetal para fins industriais e energéticos. $O$ projeto de pesquisa pretende avançar no detalhamento destes mecanismos bem como nas combinaçōes desta com outras alteraçōes significativas na escala local-regional e na escala global.

2. Pela análise prévia dos textos fornecidos ao grupo pelos Drs. Zulauf e Rodes e complementando com o estudo de F. Ramade "Ecologie des Ressources Naturelles" (MASSON, Paris, 1981), é possível extrair o seguinte:

- na emissáo total de $\mathrm{CO}_{2}$, com vistas a um reequilíbrio do ciclo biogeoquímico, metade ou mais da metade das emissóes vai para os oceanos, e o papel exato da reabsorção pela biomassa é objeto de controvérsias, especialmente na aferição dos balanços materiais envolvendo tonelagens anuais da ordem de 109 a 1010;

- a inversáo da tendência de aumento da concentraçăo e a sua possível reduçáo posterior dependerão, ao mesmo tempo, de três campos de intervenção prática:

$$
\begin{aligned}
& \text { I - diminuiçáo e interrupção do desmatamento } \\
& \text { II - } \\
& \text { recomposição da cobertura vegetal, especialmente } \\
& \text { florestal; }
\end{aligned}
$$

* Oswaldo Sevá é doutor em Geografia Humana e Organizaçăo do Espaço pela Universidade de Paris I e professor-visitante do Instituto de Estudos Avançados da USP. 


\section{III - reduçáo do aumento, estabilizaçăo e posterior diminuição das emissões da queima de combustíveis fósseis.}

3. Um programa de recomposição da cobertura flórestal no Brasil poderia ter efeitos positivos a médio prazo, considerando que a parte do país nas emissóes totais pode ser da ordem de $1 / 10$ a $1 / 6$, mas poderia também ser neutralizado a persistirem as seguintes restriçóes $\mathrm{e}$ circunstâncias atuais:

- o uso do carvão vegetal e da lenha pelas metalurgias de năo-ferrosos, pelas indústrias de ferros-ligas, pelos guseiros e pelas siderúrgicas, pelas indústrias do cimento, da cal, da cerâmica, por algumas agroindústrias ... se multiplicou por 2,5 vezes nos últimos dez anos, estando hoje na faixa de $\mathbf{3 5}$ a $\mathbf{4 0}$ milhōes de metros cúbicos (somente para as empresas filiadas à ABRACAVE, cerca de 70), dos quais apenas 6 a 7 milhōes de metros cúbicos provenientes de reflorestamento;

- a coexistência de matas e florestas nativas e secundárias

Os aspectos sociais e politicos de un tal programa sao numerosose complexos, precisariam ser abertose discutidos...

remanescentes e das futuras matas replantadas com as áreas localizadas à jusante dos ventos e das massas atmosféricas contaminadas pelas emissões da queima de combustíveis fósseis pode levar a incongruências do tipo "manter ou criar matas que serão sacrificadas pela acidificação da atmosfera".

Neste caso, os principais focos são as zonas de tráfego superdenso, as zonas de grandes caldeiras industriais, de centrais termoelétricas a óleo e a carvão, os complexos petroquímicos e carboquímicos, as refinarias de petróleo. A julgar apenas pela tonelagem, emitida de $\mathrm{SO}_{2}$, já teríamos algumas zonas consideradas críticas pelos padrōes europeus, por exemplo, em quadrículas de 100 por $100 \mathrm{~km}$, mais de $50 \mathrm{mil}$ toneladas anuais de dióxido de enxofre.

Dependendo das alturas das chaminés destas instalaçōes, dos teores de $S$ presentes no combustível e também dependendo das formas do relevo local e regional e da dinâmica meteorológica - as manchas de território atingido pela acidificação e pela formação de foto-oxidantes (O3 de baixa altitude, peroxi-acetil-nitrato, por exemplo) atingem distâncias de 50, 100, 200 ou mais $\mathrm{km}$ dos focos de emissáo. As chuvas e outras deposiçóes úmidas poderão ter o seu $\mathrm{pH}$ abaixado dos valores históricos $(6,5$ a 5,5$)$ até 4 ou menos do que 4 ; a perda de florestas é comprovada na Escandinávia, na Europa central e no Canadá, após algumas décadas de emissōes contínuas de SOx, NOx e outros poluentes.

4. Outras virtudes de um tal programa săo táo importantes quanto a possível contribuiçáo para a redução do efeito estufa, $e$ talvez 
devessem ter o mesmo grau de detalhamento na argumentação e na sugestão de áreas selecionadạs para as primeiras etapas do programa. Lembro as seguintes:

- matas ciliares e matas nas áreas de nascentes de rios;

- faixas de proteçáo em lagos artificiais de barragens e açudes (grosso modo, temos $40 \mathrm{mil} \mathrm{km}^{2}$ de espelhos d'água, e uma faixa de meio quilômetro de replantio em todos os "lagos" daria algo como $40 \mathrm{mil}$ hectares);

- faixas críticas de erosão (morros pelados, vóssorocas, pré-desertificação, trechos destruídos ou esterilizados pela mineraçáo e pelo garimpo, por exemplo).

Nestes três casos, a meta seria uma recuperação do ciclo hidrológico, com diminuiçáo da velocidade de assoreamento e, quando possível, uma reversão dos ritmos atuais de entupimento dos "lagos".

Repercussōes benéficas e urgentes podem ser esperadas: diminuiçāo do risco geotécnico em barragens, diminuição do ritmo de perda de capacidade de armazenamento e de geraçáo de energia e, principalmente, a melhoria das chances de controle e amortecimento de cheias dos rios mais caudalosos ou dos rios que atravessam áreas . urbanas.

Lembro ainda algumas outras seleções interessantes de áreas a serem replantadas:

- matas de tabuleiros (por exemplo, no litoral do Nordeste);

- sítios de fruteiras e pomares nativos ou comerciais, muitos dos quais foram destruídos pela expansão de monoculturas e de loteamentos;

- manguezais, banhados e restingas.

5. Os aspectos sociais e políticos de um tal programa são numerosos e complexos, precisariam ser abertos e discutidos; uma estratégia possível é a progressiva democratização do acesso às matas, por exemplo, na forma das reservas extrativistas (inicialmente propostas para os seringais, mas que também podem ser propostas para babaçuais e palmitais) ou, por exemplo, na forma dos bosques comunitários, com atividades mistas de criatório, cultura agrícola e coleta, como no caso dos chamados faxinais no PR e SC. Outra estratégia possível é priorizar as recomposiçóes com espécies variadas, restringindo ou vedando a exploraçáo industrial futura, incorporando áreas replantadas nas reservas ecológicas ou biológicas, ou em outros casos, na recreaçáo. 